\title{
Histone-Lysine N-Methyltransferase NSD3
}

National Cancer Institute

\section{Source}

National Cancer Institute. Histone-Lysine N-Methyltransferase NSD3. NCI Thesaurus.

Code $C 96343$.

Histone-lysine N-methyltransferase NSD3 (1437 aa, 162 kDa) is encoded by the human NSD3 gene. This protein is involved in the methylation of histones. 